Administrative Issues Journal: Connecting Education, Practice, and Research, Summer 2017, Vol. 7, No. 1: 84-106. DOI: 10.5929/2017.7.1.7

\title{
Investigation of Factors Relating to the Web-based Presentation of Policy and Information on Campus Firearm Policy and Smoking Policy
}

\author{
Veronica F. McGowan, D.Ed. \\ Southwestern Oklahoma State University
}

\begin{abstract}
In order to explore themes of privilege in regard to policy availability, language accessibility, and underlying bias, policies related to two topics of interest to higher education campus visitors, campus firearm carry policy and smoking policy, are explored to determine how Web-based information is presented to various audiences. Implications of policy accessibility are compelling; language barriers can adversely affect access to campus events and educational services. Representative samples of policies of five states that allow some form of open or concealed campus firearm carry were studied to determine possible factors of importance. Representative samples of two additional states in the more restrictive continuum of the campus carry issue were also studied as a control. In addition, policies relating to smoking were examined to determine themes related to overall policy presentation approach. Findings indicate that few Websites facilitate the provision of translated policy, and that few options exist for easy translation of policies into other languages at the point of origin. In addition, this study presents evidence that the recentness of legislative activity and desire to mitigate visitor concerns may be considered as factors impacting policy availability.
\end{abstract}

Keywords: policy language accessibility, campus policy

$\mathrm{N}$ o matter which side of the political fence an institution subscribes to on a given issue, it is a universal truth that polices related to that issue should strive to be accessible and transparent to impacted audiences. While higher educational institutions have historically enjoyed a high measure of trust, institutions are increasingly being called upon to display policies and positions that reflect their values and attitudes. In addition, the policy development process at higher educational institutions is becoming increasingly complex, with multiple levels of review increasingly incorporated. Further, with organizations such as the Association of College and University Policy Administrators (ACUPA) promoting the development of a best-practice approach to policy-making (Bruhn, 2003), an assessment of the state of dissemination practice of two policies related to politicized issues, campus firearm carry and campus smoking, is timely.

MCGOWEN / DOI: 10.5929/2017.7.1.7 
Language service policy has long been studied to determine how provision of translation services fosters access to services (Snowden \& McClellan, 2013), how political bias has been linked to policy development (Krzyżanowski \& Wodak, 2011), and how it can improve quality and performance measures (Regenstein et al., 2008). Policy language restrictions, including the use of English-only policies, have been studied in workplace settings to determine the extent that they foster discriminatory and unethical practices (Castro, 2011; Cavico, Muffler, \& Mujtaba, 2013). Yet, in higher educational settings, there is a paucity of studies relating to the importance of providing language access to institutional policy. A parallel study of the use of quality translation in research settings also noted few references in conjunction with university-sponsored research (Hendrickson et al., 2013).

Recent legislative changes in some states, combined with the large non-Native English speaking population of those states, means there should be greater activity and certainly greater need to present policy in other languages besides English. In addition to accessing educational resources, campus visitors may also access healthcare and athletic services as well as entertainment venue resources. Due to institutional sponsorship, policies of interest to campus visitors, in addition to student stakeholders, may have broad audience impact. Even removing language-related factors, public policy for various audiences may be reflecting inherited bias toward some populations in its creation (O'Brien et al., 2013; Pacheco, 2013) and implementation (Watson et al., 2014). Therefore, this paper presents an investigation into factors of how language accessibility privilege, as well as other factors, impacts the Web-based presentation of policies related to two topics of interest to campus visitors: campus firearm carry and smoking.

\section{Literature Review}

With only $56 \%$ of Californians and $65 \%$-of Texans identifying their primary language as English (United States Census Bureau, 2013), these states should be at the forefront of multi-language provision of public materials, such as public policies. As an example, Texas state mandates provision of Spanish language content on state agency Websites (Texas Health and Human Services System, 2016) and all public statefunded institutions are listed on the Website listing of Texas State Agencies (Texas Workforce Commission, 2016). Yet, a study of Texas state government Websites found that language provision compliance was only 50\% (Thornton, 2010). The underserving of policy language provision is not a problem unique to the United States. A slightly older study of United Kingdom social service organizations found that $53 \%$ had either no policy related to language provision, or the representative respondent did not know of one (Pugh \& Williams, 2006). While it is clear that compliance rates are underwhelming, what is less clear is that even if accessible policy resources existed, some populations, especially those who speak little or no English, would take advantage of those resources. For example, research procedural flaws with the way that Hispanics are grouped and classified, fail to yield significant insights into subpopulation group behaviors and experiences (Clayman et al., 2010). Even more discouraging is the overall effect of information and policy provision on recipient action; in a study of climate change, Deryugina and Shurchkov (2016) found that while information provision improved concrete knowledge related to the issue, it had little impact on pressure exerted on legislature and monetary donation to related causes.

MCGOWEN / DOI: 10.5929/2017.7.1.7 
Terry and Zhang (2016) would seem to concur; their study of smoking policy effectiveness found that policy enforcement was significantly more effective for reducing smoking rates than simply policy provision. Rose et al. (2015) had similarly low findings of public support for smoking and tobacco control point of sale informational provisions with widespread support only enjoyed with provisions related to restricted access to smoking products by minors.

In addition to linguistic diversity, such as that demonstrated in California and Texas, Ozolins (2010) posited the existence of three additional factors that impact language service policy: reliance on public sector finance, institution-led factors, and cross-sectoral interpreting needs. These factors would seem to argue for a strong presence of multiple language versions of public policy by state institutions, which are financed by public funding. However, Ticu's (2013) study conclusion that decision-makers' needs are primary to the public policies process, may indicate that policies written by stakeholders for audience consumption may be subject to or even enforce inherited bias.

\section{Firearm Policy}

While studies show that perceptions of security are not increased by policies supporting the presence of firearms (Thompson et al., 2013), firearm restrictions at various settings are easing or are being sought (114 ${ }^{\text {th }}$ United States Congress, 2015; 9th U.S. Circuit Court of Appeals, 2016; Boucher, 2015; Rizzo, 2016), including in the higher educational setting (Brooks, 2017). Higher education campus stakeholders seem to consider the campus setting to be ill-suited to increased firearm presence. A survey of statements by thirty-eight (38) private Texan universities revealed concerns on limiting educational discourse and beliefs that carry provisions will not increase campus safety (Watkins \& Murphy, 2016). In addition, institutions and state systems are increasingly codifying firearm bans and carry restrictions (Flaherty, 2016; Oklahoma State University, 2016; Ryman \& Rau, 2016), even when those restrictions are in opposition to legislative activity (Cheshire, 2016; Townes, 2016). Perhaps due to factors including federal restrictions placed on funding gun control research (McCarthy, 2013), studies regarding campus stakeholder attitudes towards campus carry and governing policy are scarce (Cavanagh et al, 2012) and owing to factors including the political nature of the subject, may be subject to variation due to the polling method (Wells, et al., 2012).

Expectations of this study are that recent state legislative activity related to the passage of concealed firearm carry in higher educational settings would result in the provision of multiple informational resources as institutions manage their messaging to various audiences. Attitudes towards issues related to campus carry may themselves reflect bias in that support groups for both sides of the issue have a strong correlation to race and gender (Benforado, 2010; Thompson et al., 2013), although studies may be compromised by a failure to accurately aggregate populations into subgroups that may demonstrate pockets of support within racial and ethnic groups (Johnson, 2013). Despite increasing public support for gun rights (Pew Research Center, 2016b) and a rise in the number of legal firearm sales in recent years (Federal Bureau of Investigation, 2014), student (Cavanaugh et al., 2012), faculty (Thompson et al., 2012), campus administrator (Price et al., 2014), and campus police (Thompson et al., 2009) support for concealed weapon campus carry policies is low. While student attitudes mirrored public attitudes up until approximately 2007 (Pew Research Center, 2016a), evidence is mounting that a rise in terrorism-related

MCGOWEN / DOI: 10.5929/2017.7.1.7 
deaths (Global Terrorism Index, 2014), homicides by shootings (Centers for Disease Control, 2014), and high-profile mass shootings (Luca, Malhotra, \& Poliquin, 2016) as well as the media's reporting of such events (McGinty, Webster, \& Barry, 2013) may have shifted public opinion in support of gun rights and policy support.

Concerning bias, there is a paucity of research related to the development of firearm policy. The literature review for this study revealed that a significant portion of current research related to the impact of mental illness on firearm policy development is conducted by a small slate of researchers. Field discussion indicates that other areas of research related to firearms have been impacted by restrictions to funding by the Centers for Disease Control (CDC) and CDC practices related to firearms research (Frankel, 2015; Hiltzik, 2016). In addition, existing implied motivations for researching firearm policymaking include those that may reflect unintentional researcher bias or subjective attitudes, such as fairness of policy initiatives (Swanson, et al., 2015), preventing barriers to mental health treatment (Barry, et al., 2013), reducing firearm trauma (Price \& Khubchandani, 2016), and prevention of stigmatization (McGinty, Webster, \& Barry, 2014). Intentional researcher bias, typically stated as recommendations to position advocates (Vizzard, 2015), may serve to obscure the missions of empirical investigations stated as policy effectiveness and feasibility studies. Because research support for firearm accessibility and firearm control is problematic due to insufficient studies resulting from issue politicization, McGinty et al.'s (2014) process model may serve as an initial framework for producing data-responsive policies in this research subfield. In addition, there is evidence that opposition to gun control by the majority of members of a particular race is impacted by societal issues (Bernforado, 2010; Pew Research Center, 2013a; Winkler, 2011), so bias may be deeply ingrained across the field, even when different frameworks are employed.

\section{Smoking Policies}

The implementation of smoking policies, with a subarea of smoke-free and tobacco ban policies, has grown exponentially in the past twenty years, with policy development covering a transition from mandatory, public space policies to a move towards voluntary, privately-owned spaces. Like firearm policy, smoking policies were highly politicized; however, as that politicization occurred earlier, before partisan shifts regarding public policy and scientific evidentiary support (Gauchat, 2012; Underwood, 2013), the number of studies linking smoking to lung and other cancers may have helped to move public option in favor of tobacco restrictions. In fact, Apollonio and Bero's (2009) study on workplace legislation process impacts found that the use of scientific evidence was the most important factor for half of the study sample. Parallel activity by public interest groups have also been cited as being instrumental in the policy development of smoke-free spaces in workplaces, restaurants, and airplanes (Brandt, 2007; Hyland, Barnoya, \& Corral, 2011). With new availability in smoking products, including vaping products, many states and higher education institutions have refined or revised their policies, so that the number of smoke-free campuses has grown significantly (Americans for Nonsmokers' Rights, 2016), ensuring that the policy has been revisited recently and remains important to stakeholders. In addition, statewide efforts at developing a statewide smoking cessation policy have increased (Krauth \& Apollonio, 2015), with impacts on provision of smoking cessation programs in hospital and mental health treatments

MCGOWEN / DOI: 10.5929/2017.7.1.7 
centers sponsored by higher education institutions expected to have an inherited impact. It is due to this recent activity, that both campus carry and smoking were considered viable for study of language accessibility and bias factors for this study.

Compared to research related to firearms, in smoking and tobacco-related research, there is significantly more activity on the development of related policy; for example, the effectiveness of anti-smoking and tobacco policies has been studied to determine its impact on behavior. Some of that research studied policy effectiveness in higher education settings. Seo et al. (2011) found that after a program intervention, smoking behavior decreased, and that smoking norms and perceptions of tobacco use changed in favor of smoke-free goals. Lechner et al. (2011) had similar theme findings, although that program was more effective for male audiences. Fallin, Roditis, and Glantz's (2015) research may best serve as a summarization of field research, as their study paralleled field discussion trends that the stronger the policy, the greater the level of compliance and attitude change occurred. Research also occurred in many societal settings. While cigarette prices may serve as a key impact on consummation behavior, correlations have been found between availability of youth smoking policies and daily smoking practices (Botello-Harbaum et al., 2009). In addition, research into factors that will influence change is necessary to develop effective policy. As an example, policies of affordable residential settings were studied to determine that newer units with a lower occupancy per-unit rate, accessed from an interior hallway, best protect vulnerable groups (Stein et al., 2015). Higher education campus settings have been the focus of some additional smoking policy research. Ickes et al. (2013) studied policy compliance to determine that an action-based intervention method was effective for reducing the amount of smoking occurring on campus. Seitz et al. (2012) examined the positive effect that a student advocacy program had for influencing policy change.

Based on this literature review, preparation for the study method invoked an awareness that the policies presented may be reflective of political attitudes and motivations of local settings. For example, it was expected that studied institutions with a strong history of providing health care and information to stakeholders would continue in this tradition in regard to smoking policy and information provision.

\section{Method}

A Web-document content analysis method (Weare \& Lin, 2000) that involved a strategic sample of Webavailable policies of institutions in states that have adopted some form of campus carry was compared to a sample representative of more restrictive practice in order to determine themes related to language provision of two campus polices likely to impact campus visitors. Samples of institutions of five states (Texas, Oregon, Mississippi, Wisconsin, and Colorado) were selected due to their relatively recent activity concerning campus carry as well as for their regional representation. As a control, institutional Web page samples from two states, California and Pennsylvania, were also analyzed as a form of control as representative samples of states on behalf of the more restrictive domain of campus carry, as well as for their regional representation. Since Texas adopted an opt-in policy for private institutions, all but one private institution have not opted-in (Watkins, 2016). With data from the pilot study indicating similar non-participation from private institutions of other states, the sample population of the research study

MCGOWEN / DOI: 10.5929/2017.7.1.7 
was narrowed to include only public institutions. In addition, due to pilot study findings that for some states state law is not yet applicable to institutions categorized as two-year, technical, or open-access institutions, a decision was made not to aggregate findings by institution type. The list of higher education institutions was obtained from state Department of Education Websites. Sixty-two institutional Websites representing the group with recent campus carry activity were searched compared to 20 sites representing the control group. For firearm policies, a total of 166 HTML items, 116 PDF items and one document items were examined. For smoking and tobacco policies, a total of $148 \mathrm{HTML}$ items and 47 PDF items were examined. Each participant institutional Web site was searched for firearm, smoking and tobacco policies that apply to public audiences; policies narrowly targeted to student audiences only were not included unless a public policy version did not exist and the policy was written as additionally applicable to the public. While the finding could be a section in a handbook, in order to be included in this study, the finding needed to be a direct link to that section, not just link to the handbook's title page. In addition, the policy or informational items must have met the standard of a permanent communication item, not a time-sensitive item such as a news item or appearance in a newsletter.

To enhance inter and intra coder reliability, two independent code reviewers received training on the coding procedure. Each of the reviewers evaluated the sample sets with two passes in differing order to insure consistency of response coding. Consensus averages of the coding reviews are presented in this study. In cases with a significant response range, an additional joint review was conducted to determine consensus. Theme analysis involved codifying categories and creating operational definitions based on theory or literature review themes (Saldana, 2000).

In order to develop the coding tool, a template was developed from literature review themes and employed with a sample of institutions from the researcher's home state. Based on this pilot study, one additional theme area, the provision of additional information and links was included in the research coding instrument due to the high number of wellness and healthy living links and advocacy information provided by institutional smoke-free initiatives.

\section{Content Themes}

For each policy review, the investigation looked for the provision of the policy in other languages beside English, or the institutional provision of a tool to facilitate translation of text, page, or document. While translation of both PDF files (TranslatePDF, 2016) and HTML pages (WorldLingo, 2016) is supported by multiple, freely available translation tools, provision of policies in HTML format should be more robust due to the ability to position a translation tool or button within the page and re-render the existing page. File attachments would typically require additional steps offsite, possibly including software download and installation. While the provision of translation tools or the fostering of Web resources that have the capacity to be translated certainly contributes to communication aims, for this study, the provision of a translated document is considered best practice due to the high number of grammatical and context errors exhibited in materials rendered by translation programs (Vidhayasai, Keyuravong, \& Bunsom, 2015).

MCGOWEN / DOI: 10.5929/2017.7.1.7 
The policy itself was examined to determine if it addressed language translation in any form, including the use of campus signage. With legislative activity allowing campuses to opt-out of concealed carry provisions for buildings which display notification signage (National Conference of State Legislators, 2016a), the readability of such signage may emerge as an issue, with best practice recommendations in favor of measures such as non-verbal signage (Schuster, 2012). The provision of a translatable Frequently Asked Questions (FAQs) page or fact sheet was also noted; presumably information provided in this form would be less formal than policy documents, which tend to contain legal terms and statements, and therefore rank higher on the accessibility scale. The existence of pages containing statements from policymakers, such as institutional or system presidents, committee presidents, etc., was also noted for its potential to contribute to a policy reader's assessment of bias. In regard to meta-data, cataloging of the total number of related pages and materials may serve as an indicator of policy importance. Finally, the sponsoring location of materials was recorded to expand on bias themes.

When policies were posted with clear policy adoption or effective dates, the date was noted to compile issue averages. Dates embedded in HTML or URL were not used as those dates may reflect other changes to a web page. Referenced state law dates were also not used as they do not explicitly address when the policy response was developed.

While the study topic of accessibility and bias could extend to policy consumers with disabilities, due to the number of factors related to Website and content accessibility for those with a disability categorization, that investigational theme was not included in this study in order to focus theme development.

\section{Findings and Discussion}

While the finding of a preponderance of English-only informational materials in this study can certainly be linked to English being the official language of the United States of America, other factors specific to the issue may be related. For example, racially motivated opposition to gun control measures among Caucasian populations (O'Brien et al., 2013) may contribute to a perception of a need to generate policy and information for that group. Recent research is indicating that a perceived rise in the number of terrorist attacks has a significant impact on development and implementation of security policy (Huddy \& Feldman, 2011).

A concerning finding was that only two sites facilitated translation with a prominent button or link available on the institutional menu bar, and therefore, available on the policy page. Both sites had a high population of English-as-a-Second Language (ESL) students. With research on commercial Websites indicating a direct correlation between fostering of native language and purchasing behavior (Forrester, 2009), implications for higher education institutions dependent on enrollment and tuition funding are clear. Studies of various at-risk populations indicate that communication barriers are a significant variable concerning access to human services such as health care and education (Fang et al., 2015; Sattin-Bajaj, 2009; Snowden \& McClellan, 2013). While measurement of accessibility errors was not part of the current study, Thorton's (2010) findings that over two-thirds of Texas state government agency Websites had 
detectable errors can be an indication of consistency with the findings of this study concerning overall accessibility.

The relatively equal proportion of materials provided as PDF documents to HTML pages seems to reflect field confusion regarding robustness of both mediums. Turro (2008) deployed the Web Content Accessibility Guidelines checklist of checkpoints to catalog PDF's degree of compliance with guidelines and catalog accessibility challenges. While some federal agencies sponsor limited adoption of PDF (United States National Archives, 2016), HTML (United States National Archives, 2014a), and ASCII (United States National Archives, 2014b) formats, interestingly, none of the studied institutions provide policy and materials in Open Document Format, despite its sponsorship by a non-profit consortium for the adoption of standards and recognition by the International Organization for Standardization (Organization for the Advancement of Structured Information Standards (OASIS), 2015a. Additional support for Open Document Format is promoted by full and limited adoption usage by North Atlantic Treaty Organization (NATO, 2016), and an American state government (Massachusetts Executive Office for Administration and Finance, 2016) as well as field discussion effectiveness (Shah, Kesan, \& Kennis, 2008) and commitment to ongoing review of accessibility (OASIS, 2016b). This confusing state of affairs in document standards may be because the United States government hasn't issued a recommendation on document dissemination, although the White House Directive does indicate that online information should be in an open format (Orszag, 2009). In this study, only $2 \%$ of institutions are improving their document accessibility by offering the policy in multiple formats.

Given the large number of institutions within the sample that exist under the umbrella of a state system, a surprising finding was that system institutions were not uniform in their policy and information approach. While nearly $50 \%$ of institutions identified as a system institution linked to some form of a system policy statement or state law, all institutions identified as a system institution set up their own policy response, resources, and information. No institutions presented evidence of a template approach to policy provision, although evidence in the form of links to other system agencies and statements provided by implementation committees indicate awareness of similar policies and some coordination between agencies as indicated by references to common workgroups, conferences, or system-sponsored events. A positive outcome of this bottom-up approach is that approximately $20 \%$ of institutions used this form of local implementation to provide links to local support agencies such as smoking cessation groups, studies, and victims support groups. In about $10 \%$ of cases, it may be said that system links served as a supplement for the local implementation in a provision of a larger set of resources.

\section{Firearm Policy}

While field findings show that $97 \%$ of campuses have a campus firearm policy (Thompson et al., 2009), that study did not address policy provision to a public campus communications portal, so this study's findings that $72 \%$ of institutions have posted a firearms policy on a Web-based portal may serve as an initial benchmark of Web-based public accessibility. Taken as a whole, provision of policy is similar for the research group ( $27 \%$ did not provide policy) and the control group ( $29 \%$ did not provide) of this study, which lends credence to field indications that campus carry policy is a national concern and less subject

MCGOWEN / DOI: 10.5929/2017.7.1.7 
to regional impacts. For the fall 2016 general election, the National Conference of State Legislatures (2016b) confirms that four states representing three regions (North-East, West, and North-West) have firearm-related statewide ballot measures, which indicates discussion in all areas is current and evolving. Despite these overall results, aggregate analysis indicated that Texas had an outsize influence on the research sample; therefore, it is reasonable to postulate that Texas's facilitation of greater information regarding policy may reflect the more prevalent gun ownership rates in the southern United States (Timmons, 2015) and awareness of the need for policy that addresses that audience in addition to other factors including the relative size of Texas systems of higher education and the need to address a larger, more diverse population. In addition, continuing legislative activity in the state of Texas regarding the campus carry issue (Allbright, 2017) may support this study's contention that legislative activity is a factor in policy information dissemination due to recent observed increases in policy address (Schafler, 2017) and calls for community input (Goard, 2017).

Three of the sample's 24 institutions that did not provide a public policy addressing firearm possession were victims of the type of high-profile mass shooting that would influence action; two of the institutional communications channels have a remembrance page dedicated to the shooting victims, so it is clear that the communicating information about the tragedy is an important institutional mission. While the finding of the lack of policy and confirmed events might be perceived as an outlier, there are no studies confirming this disconnect although field literature argues that mass shootings have an outside effect on community public policy and legislative activity (Luca, Malhotra, and Poliquin, 2016). In fact, Kleck (2009) concludes that due to the irrelevance of specific gun control measures proposed after high-profile K-12 shootings, these events in and of themselves offer poor evidentiary support for gun control legislation. Like other finding aspects of this study, the underlying issue may be multi-layered; one of the non-providing institutions was of such a small size to expect that policy development would be hindered. Vaughter, Wright, and Herbert (2015) would seem to agree that institutional size, extrapolated to mean ability to fund, impacts policy development. Their finding that sustainability policies were more likely to be adopted when the institution provided additional resources to the effort suggests a strong relationship. An additional three institutions of the sample were also sites of high-profile mass shootings; since all three of those institutions belonged to a state system, correlations regarding motivation behind policy provision cannot be stated due to the high number of confounding variables and small sample size.

Perhaps due to the need to coordinate with local and state law enforcement agencies as well as a need to effectively deal with policy enforcement, $35 \%$ of gun-related policies of the sample population were disseminated by campus enforcement, rather than another institutional sponsor. These findings seem to align with a larger study of safety audits which linked a $57 \%$ sample provision of a weapons on campus policy with campus police operation (Rasmussen \& Johnson, 2008).

While findings of the study do not support any claims that implicit bias is impacting campus carry policy formation findings, it is clear that changing opinions will continue to influence the presentation of polices on campus as evidenced by the continuum of restrictions being addressed by higher educational settings (Benning, 2016; Conway, 2016) and legislative and judicial activity (Jaschik, 2016). Further, with examples

MCGOWEN / DOI: 10.5929/2017.7.1.7 
such as faculty meeting with students in gun-restricted drinking establishments in order to avoid the campus carry policy (Martin, 2017; Nguyen, 2016), it is clear that policy implementation will continue to evolve as stakeholders grapple with the terms of policy.

\section{Joint Policy Analysis}

Recent legislative activity may be the most important factor in policy provision robustness. As an aggregate group, Texan institutions yield much more informative sites since 2016 legislative activity, with an average of 10.1 pages, than the lowest averaging state of Oregon (1.1 pages), whose most recent related legislation was in 2012. Other states with less recent campus carry legislation activity (Colorado, 2012; and Mississippi, 2011) show significantly lower item averages with averages of 1.33 , and 1.2 respectively. Wisconsin enacted a ban on weapons inside of campus buildings one week before the writing of this article. It is supposed that institutional response has yet to occur, thereby explaining the low .75 average page rating of this study. For smoking policy, Oregon's 2013 legislative activity is more recent than that related to campus carry; average number of supported pages of four per institution seems to reflect this activity. The recentness of legislative activity may also be impacting the motivation for provision of policy and information. The most commonly featured element in publically available policies and information on institutional campus carry in higher educational settings state that the purpose of campus carry information provision is to ensure or improve safety. However, several Texan institutions state additional motives for material provision that appears to have a direct tie to recent legislation activity including improving compliance (University of North Texas, 2016), protecting the rights of citizens (University of Texas at Austin, 2016) or to provide guidance on law implementation (University of Texas Medical Branch, 2016; University of Texas at San Antonio, 2016) in campus settings. To compare, Californian institutions as a whole tend not to directly address their motivation for providing policy, but seem to imply that the reason for material provision is to inform the public of legal statues and consequences (California State University, Fullerton, 2016; California State University, Long Beach, 2016; California State University, San Bernardino, 2000; University of California at Los Angeles, 2016) as well as serve reporting responsibilities (University of Southern California, 2013).

In addition to the recentness of legislative activity, other factors may contribute to the information robustness of sites in this study. In order to study the potential negative impact on reputation and recruitment activities, an association of University of Texas stakeholders has cataloged 21 incidents related to failure in retention, recruitment, and attraction of visiting speakers and artists (Gun Free UT, 2016). In fact, protection of institutional reputation may serve as a potential source of non-response bias in this study, meaning that institutions may be deliberately avoiding the provision of Web-based materials to avoid community confrontation on a politicized issue or because they feel they are out of alignment with some community stakeholders. In addition, there is field discussion that some policy formation may be in response to preventing confusion in regard to related proposed regulations, including allowing or banning firearms in faculty offices (Flaherty, 2016); protests or refusing to teach or attend class in spaces were guns are allowed or banned (Auyero, 2015); or addressing freedom of expression (Dart, 2016). It is important to note that the provision of policy materials and information are representative of the point

MCGOWEN / DOI: 10.5929/2017.7.1.7 
in time of the data collection period of December 2016 and may be affected by political and global events of that period.

Comparing language availability, smoking and tobacco policies as a whole enjoyed a $20 \%$ increase in level of provision in other languages, particularly in regard to informational materials and links such as healthy living materials, compared to the provision of firearms materials. Reasons for this increase are obscured by a lack of policy meta-data: while policy adoption or effective dates were found nearly $72 \%$ percent of the time, a full history of the revision process was rarely included. So, while there was no significant difference between the average age of smoking and tobacco policies compared to firearm policy, field discussion (Macko, 2015) indicates that smoking policies were likely only changed to address the prevalence of vapor smoking products rather than serve as a substantial change in policy form or purpose. This argument parallels findings by Meernik et al. (2016) regarding the incorporation of changes to include e-cigarettes in hospital campus policy. Therefore, it could be argued that the smoking policies are in effect older, and therefore likely to be subject to a longer scrutiny period and more likely to enjoy additional resource development such as language translation. Because of the limited access of this study, institutional "hit" data (data related to the number of visitors per page) was not collected. It is theorized that this is another underlying factor that may influence policy dissemination practices.

\section{Smoking\Tobacco Policy}

The high number of smoking cessation or health living information parallels field findings (Centers for Disease Control and Prevention, 2012) that information resources and interpersonal components were significantly more popular than other provided items, such as policy, which also confirms the large number of policies found only in PDF format. According to Pacheco (2013), "Length of exposure matters for support of future policy interventions: people exposed to smoking bans for long periods of time are more supportive of additional smoking restrictions in public places." Therefore, a logical conclusion is that Website visitors would support, even come to expect additional smoking cessation resources. In addition, Macy, Chassin and Presson's (2012) findings that adolescence smoking behaviors and attitudes correlate to later support of smoking cessation policy argues that advocacy in academic communities is a factor in policy dissemination in regard to campus health and well-being information and resources.

\section{Conclusion}

While the qualitative study method combined with relatively small sample size results in low generality, it is clear that language accessibility practices still have a long way to go. Further issues regarding Webbased transparency and communication of policy might be explored. A rich avenue for exploration might involve collecting qualitative data from samples of policy developers and stakeholders representing various groups including non-English speakers. Regarding political bias, survey investigations into political impetuses and conscious and unconscious motivations for presenting policy may serve to reveal insights into material and information sponsorship and presenting effective frameworks for varied audiences. Due to the confusion of effectiveness of document formats, studies that explore translation and languages issues would greatly supplement existing research. Studies that seek to correlate policy development to 
attitudes regarding population characteristics of race, gender, ethnicity, and personal ability and the resultant impact on social, workplace, and residential settings are also needed. Finally, it cannot be overstated that the research pool exploring firearm policy and management is critically low; of particular concern are studies of policy effectiveness in the higher education setting.

The provision of free, and easy-to-use translation tools appears to be the simplest and most effective way to increase policy access. Positioning of the tool on the institutional menu bar may foster greater access to the entire institutional Web site. In addition, institutional analysis of policies that impact a large number of people or are perceived as having a high ability to damage reputation should be considered on the short list of materials that need to be translated and checked for errors in order to maximize policy effectiveness. These interventions will not only increase accessibility compliance but will serve to model a forward-thinking institution interested in responding to diversity initiatives. For policy developers and implementers, this study makes clear that additional issues concerning document format and alignment with state organizational policy structures should be considered to offer public audiences clear and consistent messaging.

\section{References}

Allbright, C. (2017, April 16). 'Campus carry' law positioned to change upon approval of 'constitutional carry' bill. The Daily Texan. Retrieved from http://www.dailytexanonline .com/2017/04/16/\%E2\%80\%98campus-carry\%E2\%80\%99-law-positioned-to-change-uponapproval-of-\%E2\%80\%98constitutional-carry\%E2\%80\%99-bill

Americans for Nonsmokers' Rights. (2016). Going smokefree: Colleges and universities. Retrieved from http://no-smoke.org/goingsmokefree.php?id=447

Apollonio, D. E., \& Bero, L. A. (2009). Evidence and argument in policymaking: Development of workplace smoking legislation. Bio Med Central Public Health, 9, 189. doi:10.1186/1471-2458-9-189

Auyero, J. (2015, October 5). What the 'campus carry' law means for higher education. Fortune. Retrieved from http://fortune.com/2015/10/05/campus-carry-law-higher-education/

Barry, C. L., McGinty, E. E., Vernick, J. S., \& Webster, D. W. (2013). After Newtown - Public opinion on gun policy and mental illness. New England Journal of Medicine, 368, 1077-1081. doi: $\underline{10.1056 / \text { NEJMp1300512 }}$

Benforado, A. (2010). Quick on the draw: Implicit bias and the second amendment. Oregon Law Review, 89, 1-81. Retrieved from http://ssrn.com/abstract=1701089

Benning, T. (2016, August 1). UT-Dallas tweaks campus carry rules to allow faculty to ban guns in offices. Dallas News. Retrieved at https://www.dallasnews.com/news/politics/2016/08/01/campuscarry-fight-far-two-ut-schools-last-minute-allow-faculty-ban-guns-offices

MCGOWEN / DOI: 10.5929/2017.7.1.7 
Botello-Harbaum, M. T., Haynie, D. L., lannotti, R. J., Wang, J., Gase, L., \& Simons-Morton, B. (2009). Tobacco control policy and adolescent cigarette smoking status in the United States. Nicotine \& Tobacco Research, 11(7), 875-885. doi: 10.1093/ntr/ntp081

Boucher, D. (2015, March 9). Handgun permits rise as legislators try to ease laws. The Tennessean. Retrieved from http://www.tennessean.com/story/news/politics/2015/03/08/handgun-permitsrise-lawmakers-look-ease-gun-laws/24523649/

Brandt, A. (2007). The cigarette century: The rise, fall, and deadly persistence of the product that defined America. New York, NY: Basic Books.

Brooks, R. (2017, March 31). Looks like campus carry is coming to Georgia and Arkansas. USA Today College. Retrieved from http://college.usatoday.com/2017/03/31/looks-like-campus-carry-iscoming-to-georgia-and-arkansas/

Bruhn, M. (2003). A Primer on policy development for institutions of higher education. Excerpted from a chapter on "Policy Development for Improved Security" in Computer and Network Security in Higher Education, Jossey-Bass, 59-71. Retrieved from https://net.educause.edu/ir/library/pdf LSEC0501.pdf

California State University, Fullerton. (2016). Weapons policy. Retrieved from http://police.fullerton .edu/campusregulations/WeaponsPolicy.php

California State University, Long Beach. (2016). Alcohol, drugs and weapons policies: No weapons on campus. Retrieved from https://daf.csulb.edu/offices/ppfm/police/drug alcohol.html

California State University, San Bernardino. (2000). Weapons on campus. Retrieved from http://policies.csusb.edu/weapons.htm.

Castro, M. R. (2011). English only policies in the workplace: A briefing before the United States Commission on Civil Rights held in Washington, DC (United States Commission on Civil Rights, Briefing Report). Retrieved from http://purl.fdlp.gov/GPO/gpo23710

Cavanaugh, M. R., Bouffard, J. A., Wells, W., \& Nobles, M. R. (2012, December). Student attitudes toward concealed handguns on campus at 2 universities. American Journal of Public Health, 102(12): 2245-2247. doi: 10.2105/AJPH.2011.300473

Cavico, F. J., Muffler, S. C., \& Mujtaba, B. J. (2013). Language diversity and discrimination in the American workplace: Legal, ethical, and practical considerations for management. Journal of International Business and Cultural Studies. HCBE Faculty Articles. Paper 508. Retrieved from http://nsuworks.nova.edu/hcbe facarticles/508

Centers for Disease Control and Prevention. (2012, August 31). Increases in quitline calls and smoking cessation Website visitors during a national tobacco education campaign-March 19-June 10, 2012. Morbidity and Mortality Weekly Report, 61(34), 667-70. PMID: 22932300.

MCGOWEN / DOI: 10.5929/2017.7.1.7 
Centers for Disease Control and Prevention. (2014). Leading causes of death and numbers of deaths, by age: United States, 1980 and 2014 (Report from the National Center for Health Care Statistics). Retrieved from http://www.cdc.gov/nchs/data/hus/2015/020.pdf

Cheshire, C. (2016). UT Regents openly defy Texas legislature and attorney general on campus carry. Texas Scorecard. Retrieved from http://www.empowertexans.com/features/ut-regents-openly-defytexas-legislature-and-attorney-general-on-campus-carry/

Clayman, M. L., Manganello, J. A., Viswanath, K., Hesse, B. W., \& Arora, N. K. (2010). Providing health messages to Hispanics/Latinos: Understanding the importance of language, trust in health information sources, and media use. Journal of Health Communication, 15:252-263, 2. doi: 10.1080/10810730.2010.522697

Conway, M. (2016, July 13). UT-Austin faculty can ban guns in offices. The Texas Tribune. Retrieved from https://www.texastribune.org/2016/07/13/ut-regents-hear-proposed-campus-carry-rules/

Dart, T. (2016, February 24). Texas Academics told to avoid 'sensitive topics' if gun law goes into effet. The Guardian. Retrieved from https://www.theguardian.com/usnews/2016/feb/24/university-ofhouston-faculty-campus-carry-law-texas-guns

Deryugina, T., \& Shurchkov, O. (2016). The effect of information provision on public consensus about climate change. PLOS One, 11(4): e0151469. doi:10.1371/journal.pone.0151469

Ellis, L. (2017, February 14). Austin bars provide gun-free haven for UT grad students and platform for protest. Houston Chronicle. Retrieved from http://www.houstonchronicle.com/news/houstontexas/houston/article/Campus-carry-dissent-Austin-bars-provide-10932176.php

Fang. M. L., Sixsmith, J., Lawthom, R., Mountian, L., \& Shahrin, A. (2015). Experiencing 'pathologized presence and normalized absence': Understanding health related experiences and access to health care among Iraqi and Somali asylum seekers, refugees and persons without legal status. BMC Public Health, 15(1): 1-12. doi: 10.1186/s12889-015-2279-z

Flaherty, C. (2016, August 5). Even in faculty offices. Inside Higher Ed. Retrieved from https://www.insidehighered.com/news/2016/08/05/group-seeks-block-u-texas-lettingprofessors-keep-guns-out-offices

Frankel, T. C. (2015, January 14). Why the CDC still isn't researching gun violence, despite the ban being lifted two years ago. The Washington Post. Retrieved from https://www.washingtonpost.com/news/storyline/wp/2015/01/14/why-the-cdc-still-isntresearching-gun-violence-despite-the-ban-being-lifted-two-years-ago/

Federal Bureau of Investigation. (2014). 2014 National Instant Criminal Background Check System Operations Report. Retrieved from https://www.fbi.gov/file-repository/2014-nics-ops-report050115.pdf/view 
Flaherty, C. (2016). Don't go there. Inside HigherEd. Retrieved from https://www .insidehighered.com/news/2016/02/24/u-houston-faculty-senate-suggests-changes-teachingunder-campus-carry

Forrester. (2009). Translation and localization of retail Web sites. Retrieved from https://www.forrester.com/report/Translation+And+Localization+Of+Retail+Web+Sites/-/ERES54629

Gauchat, G. (2012, April). Politicization of science in the public sphere: A study of public trust in the United States, 1974 to 2010. American Sociological Review, 77(2), 167-187. doi: $\underline{10.1177 / 0003122412438225}$

Global Terrorism Index. (2014). Deaths from terrorism, 2000-2014. Retrieved from http://www.abc.net.au/news/2015-11-17/global-terrorism-index/6947406

Goard, A. (2017, April 16). ACC asks its community for input on campus carry. KXAN News. Retrieved from http://kxan.com/2017/04/16/acc-asks-its-community-for-input-on-campus-carry/

Gun Free UT. (2016). The impact of campus carry: recruitment, retention, reputation damage. Retrieved from http://gunfreeut.org/resources/impact-of-campus-carry/

Hendrickson, S. G., Harrison, T. C., Lopez, N. A., Zegarra-Coronado, A. G., \& Ricks, T. (2013). Translation cost, quality, and adequacy. Journal of Nursing Scholarship, 45(2), 185-191. doi: 10.1111/inu.12021

Hiltzik, M. (2016, June 14). The NRA has blocked gun violence research for 20 years. Let's end its stranglehold on science. Los Angeles Times. Retrieved from http://www.latimes.com/business/hiltzik/la-fi-hiltzik-gun-research-funding-20160614-snapstory.html

Huddy, L., \& Feldman, S. (2011, September). Americans respond politically to $9 / 11$ understanding the impact of the terrorist attacks and their aftermath. American Psychologist, 66(6), 455-467. doi:10.1037/a0024894

Hyland, A., Barnoya, J., \& Corral, J. E. (2012). Smoke-free air policies: Past, present and future. Tobacco Control, 21, 154-161. doi:10.1136/tobaccocontrol-2011-050389

Ickes, M. J., Hahn, E. J., McCann, M., \& Kercmar, S. (2013). Tobacco-free take action!: Increasing policy adherence on a college campus. Policy Studies Organization, 5(1). 47-56. doi: $\underline{10.1002 / w m h 3.2}$

Jaschik, S. (2016, August 11). U Texas to punish professors who bar guns from class. Inside HigherEd. Retrieved from https://www.insidehighered.com/quicktakes/2016/08/11/u-texas-punishprofessors-who-bar-guns-class

Johnson, N. J. (2013). Firearms policy and the black community: An assessment of the modern orthodoxy. Connecticut Law Review, 45(5). Retrieved from Fordham Law Archive of Scholarship and History, ir.lawnet.fordham.edu

MCGOWEN / DOI: 10.5929/2017.7.1.7 
Kleck, G. (2009). Mass shootings in schools: The worst possible case for gun control. American Behavioral Scientist, 52(10), 1447-1464. doi: 10.1177/000276420933255

Krauth, D., \& Apollonio, D. E. (2015). Overview of state policies requiring smoking cessation therapy in psychiatric hospitals and drug abuse treatment centers. Tobacco Induced Diseases, 13, 33. doi: 10.1186/s12971-015-0059-2

Krzyżanowski, M. \& Wodak, R. (2011). Political strategies and language policies: the European Union Lisbon strategy and its implications for the EU's language and multilingualism policy. Language Policy, 10, 115. doi:10.1007/s10993-011-9196-5

Lechner, W. V., Meier, E., Miller, M. B., Wiener, J. L., \& Fils-Aime, Y. (2011). Changes in smoking prevalence, attitudes, and beliefs over 4 years following a campus-wide anti-tobacco intervention. Journal of American College Health, 60(7). SPORTDiscus Database \# 80231784.

Luca, M., Malhotra, D. K., \& Poliquin, C. (2016). The impact of mass shootings on gun policy. Harvard Business School NOM Unit Working Paper No. 16-126. doi: 10.2139/ssrn.2776657

Macko, C. (2015, October 7). On-campus smoking ban met with mixed reception, muddled clarity. The State News. Retrieved from http://statenews.com/article/2015/10/smoking-ban-enforcementunsure

Macy, J. T., Chassin, L, \& Presson, C. C. (2012, July). Smoking behaviors and attitudes during adolescence prospectively predict support for tobacco control policies in adulthood. Nicotine \& Tobacco Research, 14(7), 871-879. doi: 10.1093/ntr/ntr301

Massachusetts Executive Office for Administration and Finance. (2016). Open Document Format/Open $X M L . \quad$ Retrieved from http://www.mass.gov/anf/research-and-tech/it-serv-andsupport/application-serv/open-initiatives/open-document-formatopen.html

McCarthy, M. (2013). Reviving research into US gun violence. British Medical Journal, 346, f980. doi: 10.1136/bmj.f980.

McGinty, E. E., Webster, D. W., \& Barry, C. I. (2013). Effects of news media messages about mass shootings on attitudes toward persons with serious mental illness and public support for gun policies. American Journal of Psychiatry, 170, 494-501. doi: 10.1176/appi.ajp.2013.13010014

McGinty, E. E., Webster, D. W., \& Barry, C. I. (2014). Gun policy and serious mental illness: Priorities for future research and policy. Psychiatric Services, 65(1), 50-58. doi: 10.1176/appi.ps.201300141

McGinty, E. E. Frattaroli, S., Appelbaum, P. S., Bonnie, R. J., Grilley, A., ...\& Webster, D. W. (2014). Using research evidence to reframe the policy debate around mental illness and guns: Process and recommendations. American Journal of Public Health, 104(11), e22-6. doi: 10.2105/AJPH.2014.302171

Meernik, C., Baker, H.M., Paci, K., Fischer-Brown, I., Dunlap, D., \& Goldstein, A. O. (2015). Electronic cigarettes on hospital campuses. International Journal of Environmental Research And Public Health, 13(1). doi: 10.3390/ijerph13010087 
National Conference of State Legislators. (2016a). Guns on campus: Overview. Retrieved from http://www.ncsl.org/research/education/guns-on-campus-overview.aspx

National Conference of State Legislatures. (2016b). NCSL state vote 2016: Statewide ballot measures. Retrieved from http://www.ncsl.org/research/elections-and-campaigns/statevote-2016.aspx

Nguyen, V. (2016, September 30). Graduate students hold gun-free office hours at off-campus bar. The Daily Texan. Retrieved from http://www.dailytexanonline.com/2016/09/30/graduate-studentshold-gun-free-office-hours-at-off-campus-bar

North Atlantic Treaty Organization. (2016). D.5. User facing capabilities. NATO Interoperability Standards and Profiles. Retrieved from https://nhqc3s.hq.nato.int/Apps/Architecture/NISP/volume3 Lapds05.html

O’Brien, K. Forrest, W., Lynott, D., \& Daly, M. (2013). Racism, gun ownership and gun control: Biased attitudes in US whites may influence policy decisions. PLOS. doi:10.1371/journal.pone.0077552

Oklahoma State University Faculty Council. (2016). 2016 Gun resolution. Retrieved from https://facultycouncil.okstate.edu/content/2016-gun-resolution

Organization for the Advancement of Structured Information Standards. (2015a). OASIS Open Document Format for Office Applications (OpenDocument) TC. Retrieved from https://www.oasisopen.org/committees/tc home.php?wg abbrev=office

Organization for the Advancement of Structured Information Standards. (2015b). OpenDocument Accessibility SC. Retrieved from https://www.oasis-open.org/committees/tc home .php?wg abbrev=office-accessibility

Orszag, P. R. (2009). Open government directive. Memorandum from the Office of Management and Budget (OMB). Retrieved from https://www.whitehouse.gov/open/documents/opengovernment-directive

Ozolins, U. (2010, July). Factors that determine the provision of public service interpreting: Comparative perspectives on government motivation and language service implementation. The Journal of Specialised Translation, 14. Retrieved from http://www.jostrans.org/issue14/art ozolins.pdf

Pacheco. J. (2013, Fall). Attitudinal policy feedback and public opinion the impact of smoking bans on attitudes towards smokers, secondhand smoke, and antismoking policies. Public Opinion Quarterly, 77(3), 714-734. Social Sciences Citation Index \# 000326187900004.

Pew Research Center. (2013a). Gun rights proponents more politically active: In gun control debate, several options draw majority support (Pew Research Center report). Retrieved from http://www.people-press.org/files/legacy-pdf/01-14-13\%20Gun\%20Policy\%20Release.pdf

Pew Research Center. (2013b). Perspectives of gun owners, non-owners: Why own a gun? protection is now top reason. Pew Research Center report. http://www.people-press.org/2013/03/12/whyown-a-gun-protection-is-now-top-reason/Accessed27/03/2013

MCGOWEN / DOI: 10.5929/2017.7.1.7 
Pew Research Center. (2016ba).Gun rights vs. gun control (Pew Research Center report). Retrieved from http://www.people-press.org/2016/08/26/gun-rights-vs-gun-control/\#total

Pew Research Center. (2016b). Opinions on gun policy and the 2016 campaign (Pew Research Center report). Retrieved from http://www.people-press.org/2016/08/26/opinions-on-gun-policy-andthe-2016-campaign/

Price, J. H., \& Khubchandani, J. (2016, June). Firearm violence by the mentally ill: Mental health professionals' perceptions and practices. Violence and Gender, 3(2): 92-99. doi:10.1089/vio.2015.0045

Price, J. H., Thompson, A., Khubchandani, J., Dake, J., Payton, E., \& Teeple. K. (2014). University presidents' perceptions and practice regarding the carrying of concealed handguns on college campuses. Journal of American College Health, 62(7). doi: 10.1080/07448481.2014.920336

Pugh, R., \& Williams, D. (2006). Language policy and provision in social service organizations. British Journal of Social Work, 36, 1227-1244. doi:10.1093/bjsw/bch384

Rasmussen, C., \& Johnson, G. (2008). The ripple effect of Virginia Tech: Assessing the nationwide impact on campus safety and security policy and practice. Midwestern Higher Education Compact. ERIC Database \#ED502232.

Regenstein, M., Huang, J., West, C., Mead, H., Trott, J., \& Stegun, M. (2008). Hospital language services: quality improvement and performance measures. Advances in patient safety: new directions and alternative approaches. Rockville, MD: Agency for Healthcare Research and Quality. Retrieved from http://www.ahrq.gov/downloads/pub/advances2/vol2/advancesregenstein 54.pdf

Rizzo, S. (2016, April 8). Christie eases gun rules, says N.J.'s restrictions have led to tragedy. The Record. Retrieved from http://www.northjersey.com/news/christie-issues-guidelines-to-streamline-gunpermit-process-1.1541305

Rose, S. W., Emery, S. L., Ennett, S., McNaughton-Reyes, H. L., Scott, J. C., \& Ribisi, K.M. (2015). Public support for family smoking prevention and tobacco control act point-of-sale provisions: Results of a national study. American Journal of Public Health, 105(10). doi: 10.2105/AJPH.2015.302751

Ryman, A., \& Rau, A. B. (2016, January 22). Arizona Regents vote to oppose guns-on-campus bill. Arizona Republic. Retrieved from http://www.azcentral.com/story/news/arizona/politics L2016/01/20/arizona-regents-vote-oppose-guns-campus-bill/79060950/\#

Saldana, J. (2009).The coding manual for qualitative researchers. Thousand Oaks, CA:Sage.

Sattin-Bajaj, C. (2009). Informing Immigrant Families about High School Choice in New York City: Challenges and Possibilities (Report from Vanderbilt University, National Center on School Choice). ERIC Database \# ED509551.

MCGOWEN / DOI: 10.5929/2017.7.1.7 
Schafler, K. (2017, April 14). Lone Star College Board revises campus carry policy. The Courier. Retrieved from http://www.yourconroenews.com/news/article/Lone-Star-College-board-revises-campuscarry-11074168.php

Schuster, M. (2012). Language accessibility of signage in public settings: A case study of a health care service. Southern African Linguistics and Applied Language Studies 2012, 30(3), 311-324. Retrieved from http://sunzi.lib.hku.hk/hkuto/record/B42931514

Seitz, C. M., Strack, R. W., Rice, R., Moore, E., DuVall, T., \& Wyrick, D. L. (2012). Using the photovoice method to advocate for change to a campus smoking policy. Journal of American College Health, 60(7). SPORTDiscus database \# 07448481.

Seo, D. C., Macy, J. T., Torabi, M. R., \& Middlestadt, S. E. (2011). The effect of a smoke-free campus policy on college students' smoking behaviors and attitudes. Preventive Medicine, 53, 347-352. doi: 10.1016/i.ypmed.2011.07.015

Shah, R. C., Kesan, J. P., \& Kennis, A. (2008). Lessons for government adoption of open standards: A case study of the Massachusetts policy. Journal of Information Technology \& Politics, 5(4), 387-398. doi: $\underline{10.1080 / 19331680802579366}$

Snowden, L. R., \& McClellan, S. R. (2013). Spanish-language community-based mental health treatment programs, policy-required language assistance programming, and mental health treatment access among Spanish-speaking clients. American Journal of Public Health, 103(9). doi:10.2105/AJPH.2013.301238

Stein, A., Suttie, J., Baker, L., Agans, R., Xue, W., \& Bowling, M. (2015). Predictors of smoke-free policies in affordable multiunit housing, North Carolina, 2013. Preventing Chronic Disease, 12, 140506. doi: $\underline{10.5888 / p c d 12.140506}$

Swanson, J. W., McGinty, E. E., Fazel, S. \& Mays, V. M. (2015). Mental illness and reduction of gun violence and suicide: Bringing epidemiologic research to policy. Annals of Epidemiology, 25(5), 366-376. doi: 10.1016/j.annepidem.2014.03.004

Terry, A., \& Zhang, N. J. (2016, February). The impact of tobacco-free school policies on youth smoking rates in Florida public school districts. Journal of School Health, 86(2), 129-134. doi: $\underline{10.1111 / \text { josh.12360 }}$

Texas Health and Human Services System. (2016). HHS EIR Accessibility policy, Chapter 11: Spanish Language Translation, 1 TAC $\$ 206.51(a)$. Retrieved from http://accessibility .hhs.texas.gov/policy htm/ch11.htm

Texas Workforce Commission (2016). Websites of Texas state agencies \& state-funded institutions. Retrieved from http://www.twc.state.tx.us/jobseekers/Websites-texas-state-agencies-statefunded-institutions

MCGOWEN / DOI: 10.5929/2017.7.1.7 
Thompson, A., Price, J. H., Dake, J. A., \& Teeple, K. (2012). Faculty perceptions and practices regarding carrying concealed handguns on university campuses. Journal of Community Health, 38(2), 366373. doi: $10.1007 / \mathrm{s} 10900-012-9626-0$

Thompson, A., Price, J. H., Dake, J. A., Teeple, K., Bassler, S., ... \& Stratton, C. (2013). Student perceptions and practices regarding carrying concealed handguns on university campuses. Journal of American College Health, 6(5), 243-53. doi: 10.1080/07448481.2013.799478

Thompson, A., Price, J. H., Mrdjenovich, A. J., \& Khubchandani, J. (2009). Reducing firearm-related violence on college campuses-police chiefs' perceptions and practices. Journal of American College Health, 58(3), 247-254. doi: 10.1080/07448480903295367

Thorton, R. A. (2010). Texas state agency Websites: A descriptive assessment of attributes that support online citizen engagement. (Masters Thesis). Texas State University - San Marcos. Retrieved from https://digital.library.txstate.edu/bitstream/handle/10877/3720/fulltext.pdf?sequence=1.

Ticu, D. (2013). Theories of motivation in public policies process. Lumen International Conference Logos Universality Mentality Education Novelty (LUMEN 2013). Procedia-Social and Behavior Sciences, 92, 925 - 929. Retrieved from www.sciencedirect.com

Timmons, H. (2015, July 24). Mapped: The US states with the most gun owners-and most gun deaths. Quartz. Retrieved from http://qz.com/437015/mapped-the-us-states-with-the-most-gunowners-and-most-gun-deaths/http://qz.com/437015/mapped-the-us-states-with-the-most-gunowners-and-most-gun-deaths/

Townes, C. (2016, May 3). Tennessee approves guns on college campuses. ThinkProgress. Retrieved from https://thinkprogress.org/tennessee-approves-guns-on-college-campuses68472c8c331a\#.5r5w1myle

Translate PDF. (2016). Translate any file. Retrieved from http://translatepdf.com/index.html.

Turro, M. R. (2008, September). Are PDF documents accessible? Information Technology \& Libraries. 27(3), 25-43. Library, Information Science \& Technology Abstracts Database \# 34231359.

Underwood, E. (2013). Gun control agenda is a call to duty for scientists. Science, 339(6118), 381-382. Environment Complete database \# 85275006.

United States Census Bureau. (2015). Detailed Languages Spoken at Home and Ability to Speak English for the Population 5 Years and Over: 2009-2013. Retrieved from http://www.census .gov/data/tables/2013/demo/2009-2013-lang-tables.html

9th U.S. Circuit Court of Appeals. (2016). Teixeira v. County of Alameda. Retrieved from https://cdn.ca9.uscourts.gov/datastore/opinions/2016/05/16/13-17132.pdf

$114^{\text {th }}$ United States Congress. (2015). H.R.1735 - National Defense Authorization Act for Fiscal Year 2016. Retrieved from https://www.congress.gov/bill/114th-congress/house-bill/1735

MCGOWEN / DOI: 10.5929/2017.7.1.7 
United States National Archives. (2016). PDF: Portable Document Format. Retrieved from https://www.archives.gov/preservation/products/definitions/pdf.html

United States National Archives. (2014a). Appendix A: Tables of file formats: 10. Web Records. Retrieved from https://www.archives.gov/records-mgmt/policy/transfer-guidancetables.html\#Webrecords

United States National Archives. (2014b). ARCIS/MRS MRF customer Web portal: MTF user guide. Retrieved from https://www.archives.gov/files/st-louis/military-personnel/agencies/ARCISMRSmtf-customer-Web-portal-mtf-user-guide.pdf

University of California at Los Angeles. (2016). UCLA Policy 131: Weapons on university property. Retrieved from http://www.adminpolicies.ucla.edu/pdf/131.pdf.

University of North Texas. (2016). Campus carry: Overview. Retrieved from https://campuscarry.unt.edu/

University of Southern California. (2013). Policy: Violence-free campus. Retrieved from https://policy usc.edu/violence-free-campus/

University of Texas at Austin. (2016). Campus carry: General information. Retrieved from http://campuscarry.utexas.edu/

University of Texas Medical Branch. (2016). About campus carry at UTMB. Retrieved from https://www.utmb.edu/campus-carry/

University of Texas at San Antonio. (2016). Campus carry: Frequently asked questions. Retrieved from http://www.utsa.edu/campuscarry/faqs.html\#q1

Vaughter, P., Wright, T., \& Herbert, Y. (2015). 50 shades of green: An examination of sustainability policy on Canadian campuses. Canadian Journal of Higher Education, 45(4), 81-100. ERIC database \# EJ1086836.

Vidhayasai, t., Keyuravong, S., \& Bunsom, T. (2015). Investigating the use of google translate in "Terms and Conditions" in an airline's official Website: Errors and implications. PASAA Journal, 49, 137169. Retrieved from ERIC database \# EJ1077919.

Vizzard, W. J. (2015). The current and future state of gun policy in the United States. The Journal of Criminal Law \& Criminology, 104(4), 879-904. doi: 0091-4169/15/10404-0879

Watkins, M. (2016, July 29). Only one private Texas university adopting campus carry. The Texas Tribune. Retrieved from https://www.texastribune.org/2016/07/29/all-one-private-university-texas-areopting-out-ca/

Watkins, M. \& Murphy, R. (2016, July 29). Where Texas' private universities stand on campus carry. Texas Tribune. Retrieved from https://apps.texastribune.org/private-university-campus-carry/

Watson, J., Pape, L., Murin, A., Gemin, B. \& Vashaw, L. (2014). Keeping pace with k-12 digital learning: An annual review of policy and practice. Eleventh Edition (Report from Evergreen Education Group). ERIC Database \# ED558147.

MCGOWEN / DOI: 10.5929/2017.7.1.7 
Weare, C., \& Lin, W. Y. (2000). Content analysis of the World Wide Web: Opportunities and challenges. Social Science Computer Review, 18(3), 272-292. doi: 10.1177/089443930001800304

Wells, W., Cavanaugh, M. R., Bouffard, J. A., \& Nobles, M. R. (2012). Non-response bias with a Web-based survey of college students: Differences from a classroom survey about carrying concealed handguns. Journal of Quantitative Criminology, 28, 455-476. doi: 10.1007/s10940-011-9148-4

Winkler, A. (2011) Gunfight: The battle over the right to bear arms in America. New York, N.Y. London: W.W. Norton.

WorldLingo. (2016). Free Website translation. Retrieved from http://www.worldlingo .com/en us/Websites/url translator.html

\section{About the Author}

Dr. Veronica McGowan, D.Ed. (veronica.mcgowan@swosu.edu) serves as a Teaching and Learning Coordinator and Assistant Professor at Southwestern Oklahoma State University. Dr. McGowan is the Vice President of the Board of Education at the Insight School of Oklahoma, a public virtual charter school for grades 7-12 in Midwest City, Oklahoma. McGowan is the past President of the Board of the Computing Teachers Network of the International Society of Technology in Education. She previously served as Editorin-Chief of the Journal for Computing Teachers; she now serves on its Review Board. She was a Middle States Evaluator and Program Reviewer for the Council for the Accreditation of Educator Preparation (CAEP) for several years, and currently serves as an Assessment Expert for the Accreditation Council for Business Schools and Programs (ACBSP). 